
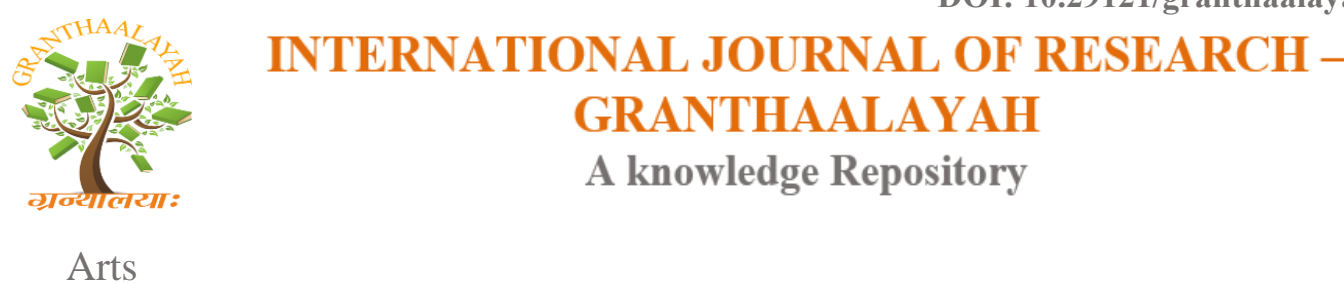

\title{
ADAPTATION OF DESIGNS FOR TEXTILE PRODUCTS INSPIRED FROM MADHUBANI PAINTING
}

\author{
Dr. Mohini Gupta ${ }^{* 1}$, Swati Gangwar ${ }^{2}$ \\ ${ }^{* 1}$ Assistant Professor, Pushp Institute of Sciences \& Higher Studies Pilibhit, Uttara Pradesh, \\ INDIA \\ ${ }^{2}$ M.Sc Student, Pushp Institute of Sciences \& Higher Studies Pilibhit, Uttara Pradesh, INDIA
}

\begin{abstract}
Madhubani art of the Bihar state has been undergoing transition where its application in original composition has been declined owing to social and economic changes now-a-days. There is need to explore possibilities for the conservation of this art form viz other artistic media for future generations. The reason for using traditional motifs in textiles is to keep our designs or motifs alive. The Indian folk arts with painting play important role in creating new designs. Escalating demands of consumers requires modification in the fashion industry with respect to design, colour, style and technique. So in an effort to add another dimension in the application of Madhubani designs on textiles, the present study was planned. The effort was targeted towards finding the possibility of applying Madhubani designs on textile articles utilizing the hand painting. Madhubani motifs/designs were adapted for center design and border design. Total thirty six motifs / designs were developed keeping in mind their suitability for articles like cushion cover, folder and table cloth. Developed design sheets were subjected to visual evaluation for selection of one best design in each category by the panel of thirty respondents to find out the suitability of the developed designs for hand painting. Finally three articles were prepared by using selected designs and these prepared articles were highly appreciated by the respondents.
\end{abstract}

Keywords:

Madhubani painting, textile designing, Adaptation, Hand painting, Motif/designs, fusion.

Cite This Article: Dr. Mohini Gupta, and Swati Gangwar, “ADAPTATION OF DESIGNS FOR TEXTILE PRODUCTS INSPIRED FROM MADHUBANI PAINTING” International Journal of Research - Granthaalayah, Vol. 4, No. 5 (2016): 115-125.

\section{INTRODUCTION}

Indian art history is a rich storage of traditional painting from pre-history to present time. Throughout its history, Indian art has combined local tradition with outside influences, and the art has evolved along with the Indian civilization, the effect of which has been remarkably innovative in different spheres. The lesser known historicity of original art forms in India is 
known as "folk-art" carries a unique history and individuality with itself. Folk in a sense carries the connotation of anonymity, collective wisdom, spontaneity and simplicity. These are living traditions, intrinsically linked with the regional historic-cultural setting from which they arise. The term 'folk paintings' here encompasses the art in Indian villages whereby people indulge in art without any proper training, basically for ornamentation of their abodes and for the portrayals of their Gods for rituals chiefly in the form of wall and floor painting.

The wall-painting or Mural paintings is popularly known as Mithila painting or Madhubani painting practiced in the Mithila region of Bihar state, India. Madhubani paintings mostly represent the men and its association with nature and divinity from the ancient epics. Natural objects like the sun, the moon, and religious plants like tulsi are also widely painted, along with sense from the royal court and social event like weddings. Generally no space is left empty since the gaps are filled by paintings of flowers, animals, birds, and even geometric design. Madhubani painting is the indication of the philosophical heights achieved by Indian civilization for the universal power of love, longing and peace. The beauty of the Madhubani painting is the exploration of the relationship between nature, culture and human psyche and the use of raw material i.e available to them in plenty. Through these paintings innermost desires, dreams, aspirations, expectations and fantasies are expressed by mithila folk women. The Indian folk art form of Madhubani is now recognized worldwide and succeeded in creating a place for itself in the international house of fame. The Government of India is also paying its tribute by starting training programs for educating people on Madhubani paintings [1]

The artisan of Madhubani paintings are used colours directly from nature. Lamp soot served as a source of black, White from powdered rice, green was made from the leaves of the apple tree and Tilcoat, blue from the seeds of Sikkot and indigo, yellow was drawn from the parts of singar flower or Jasmine flower, bark of peepal was to be boiled to make a part of saffron colour, red was made from kusum flower and red sandal wood. To make the painting last long as well as o take brightness they mixed gum with colour [2].

The colours, designs and styles keep on adapting to the changing tastes and fashions as man's aesthetic sense motivates him to introduce grace and elegance into the monotony and drabness which leads gradually to new decorative designs through fine form, colour and style. The different designs are introduced on cloth by means of embroidery, printing, painting, applique, etc. [3].

Designing is an art and the art is a product of the creative process. It is the human power to conceive, plan and realize the products that serves human beings in the accomplishment of any individual or collective purpose [4].

Mithila paintings are generally done on jute bags, sarees, other apparel, pen holder, mobile covers etc. to beautify their appearance therefore it is also a part of handicraft work. Handicraft can be define simply as object made by the skill of the hand and which carry a part of the creator as well as centuries of the evolutionary tradition. Going by industry group, after agriculture, a sizeable number of informal sector workers are engaged in trade and manufacturing related to small scale industries and traditional industries covering Khadi and Village Industries, Sericulture, Coir and Handicrafts (Textile printing, blue pottery, jewellery, Carving Stone, 
Leather etc), Handlooms, Power looms. In India, craft is the second largest employer of people living in rural areas after agriculture, and the sector, has employment requirements for millions of people, whose livelihoods and income are dependent on selling their craft [5].

\section{ORIGIN OF MITHILA}

Madhubani paintings is believed to be originated from the town of Madhubani of Mithila in the North Indian state of Bihar. The exact reason or time of the origination of Madhubani art is unknown. However, the legend has it that it came into vogue during the time of Ramayana, when Janak ordered the artists in his own kingdom to make beautiful paintings for the wedding of his daughter Sita, to Lord Rama. This art, with a tradition going back to the centuries, is today an exclusive monopoly of women artists. They paint figures from nature and myth on household and village walls to mark the seasonal festivals of the religious year, for special events of the life-cycle, and when marriages are being arranged they prepare intricately designed wedding proposal. Initially, the women in Madhubani sarted making the paintings on the walls of their huts. With time, the artists began creating Madhubani art on paper, cloth and canvas also [6].

\section{CHARACTERISTIC [6]}

In Mithila, this painting is done in three forms.

Painting on Floor: Painting is made on the floor with the paste of crude (arva) rice, this paste is called "pithar" in the local language. Apart from the floor it is also made on banana leaves and pidhi (wooden seats). A women or a girl does it using her right hand's fingertips. In tusari puja, a festival celebrated by the unmarried girls in order to please Gauri and Shiva to have a suitable husband, this painting is made with dry rice powder in white, yellow and red colours. These are made in different types suiting different occasions.

Paintings done on walls: Wall paintings are multicoloured. Three to four colours are usually used to depict the paintings. Pictures include those of carriers of fish, curd, jackfruit, trees of fruits such as mango and pomegranate and birds like peacock. Attractive floral motifs adorn the wall on four sides of the entrance.

Paintings on movable objects: It includes those on clay models of pots, elephants, birds, bamboo structure, mats, fan and objects made of sikkhi (thin wood). Decorative multi coloured designs made on the faces of the brides and sumangalis also fall in this category. Many of these paintings have great tantric significance.

\section{MATERIAL AND METHOD}

The aim of the study was to create a design Sheets, by the adaption of Madhubani designs of Bihar region for textile designing through hand painting. 


\subsection{COLLECTION OF MADHUBANI DESIGNS}

Traditional designs of Madhubani painting of the Bihar region were collected for the study from various secondary sources like books, cards, internet and library.

\subsection{ADAPTATION OF MADHUBANI DESIGNS FOR HAND PAINTING}

The selected motifs were used to develop designs sheets for hand painting. Thirty six designs in different categories i.e., center design and border designs were adapted to make them suitable for hand painting. The designs were developed keeping in mind their suitability for articles.

\subsection{EVALUATION OF DESIGN SHEETS}

Development of designs sheets for textile article was followed by the preferences of respondents for identifying the best design for preparing each article inspired from Madhubani painting. The developed designs were shown to 30 respondents in the age group of 20-35 years, selected randomly which included faculty members of the Department of Home Science and PG students. The respondents were evaluated the one developed design for each article on the basis of motifs. Weighted mean scores (WMS) were calculated and ranks were assigned to the developed designs. The designs of all the articles which obtained highest rank were considered best for preparing articles.

\subsection{PREPARATION OF ARTICLE}

Finally three articles namely cushion folder and table cloth were developed using one preferred design by the respondent. The prepared articles were evaluated by 30 consumer to assess their acceptability and colour combination, innovativeness, overall appearance using three point rating scale.

\section{RESULT AND DISCUSSION}

\section{ADAPTATION AND EVALUATION OF DESIGN SHEETS}

Total thirty six designs were developed. Designs/motifs were shown in Fig-1 to3. The total scores were calculated for each design where the one design which scores highest rank were selected as a most preferred design in each category. The score of selected design were shown in Fig 4 to 6. 

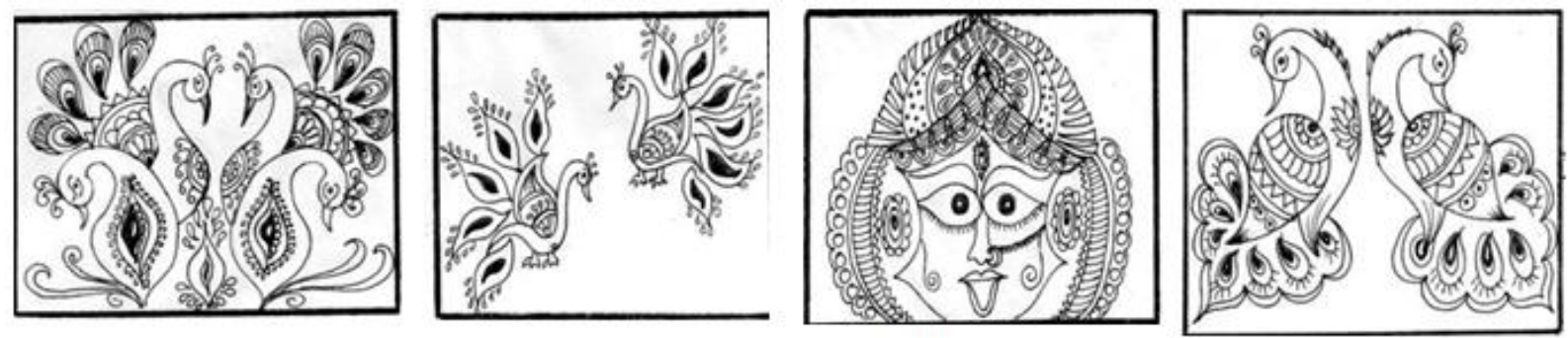

$\mathrm{C} 2$

C3
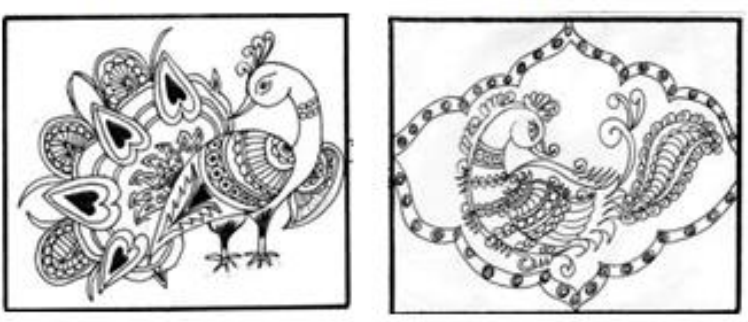

C6

C7

$\mathrm{C} 4$

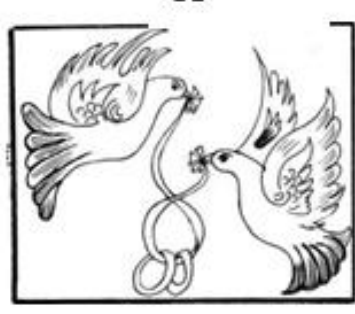

C5

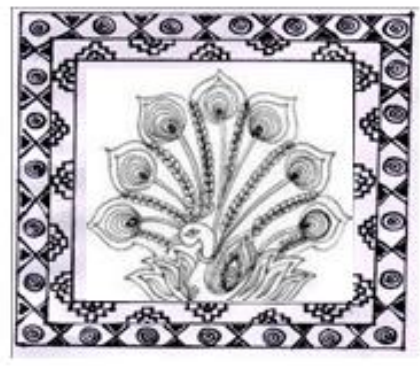

$\mathrm{Cl0}$

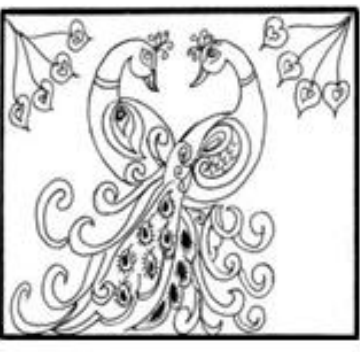

$\mathrm{Cll}$

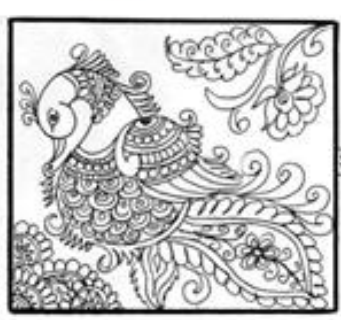

C8

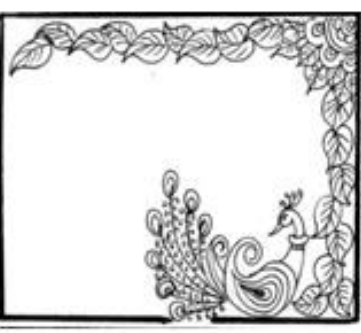

C9

Figure 1: DESIGN FOR CUSHION COVER

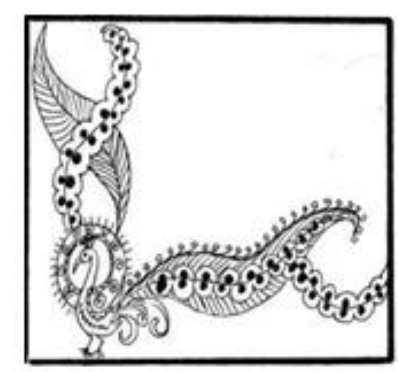

$\mathrm{C12}$ 


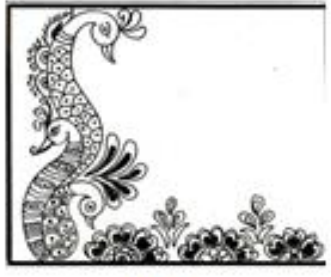

F1

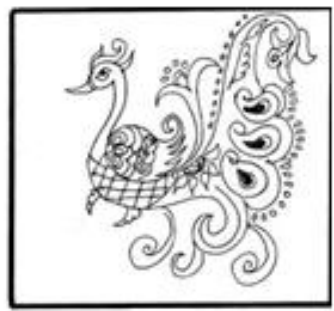

F5

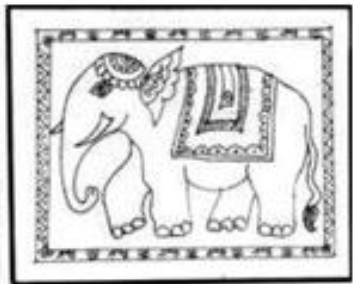

F9

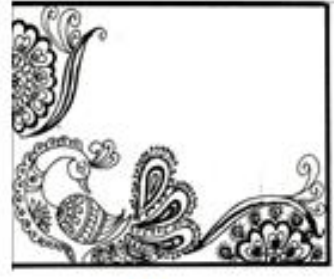

F2

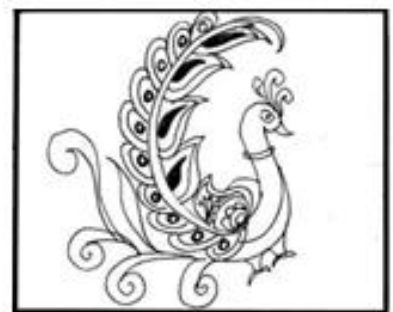

F6

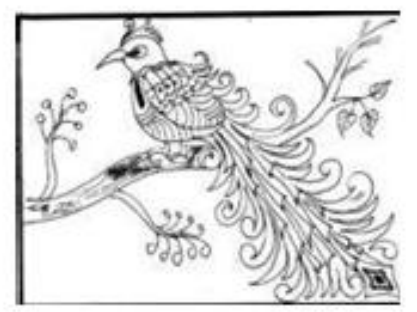

F10

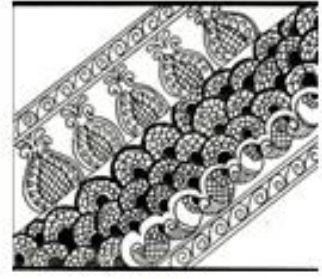

F3

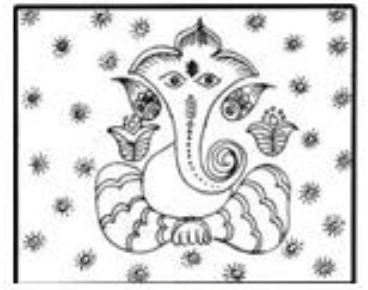

F7

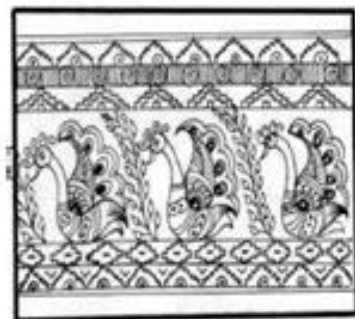

F11

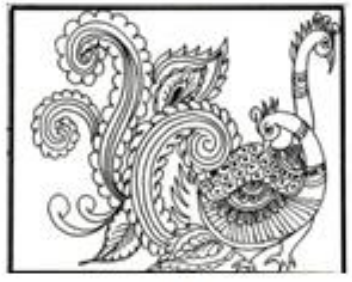

F4

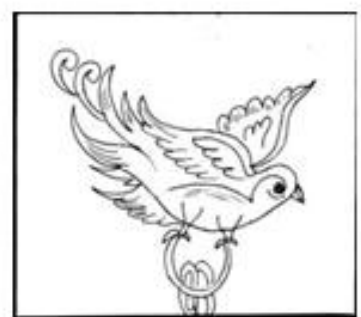

F8

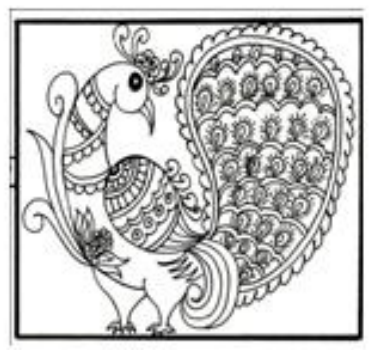

F12

Figure 2: DESIGN FOR FOLDER 


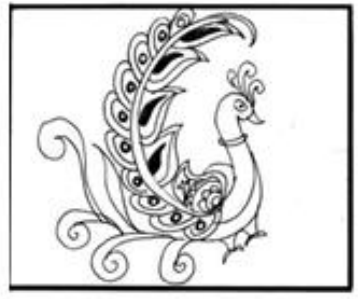

Tl

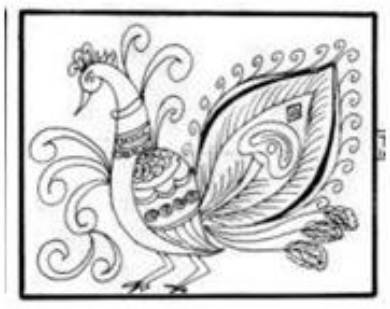

T5

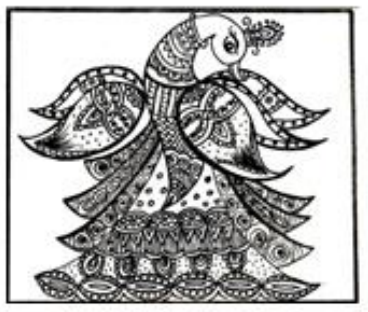

T9

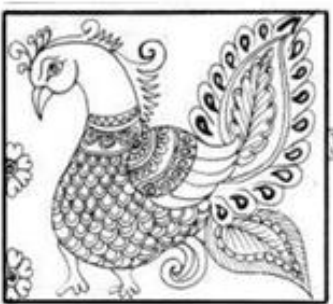

T2

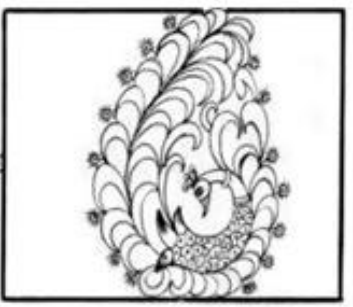

T6

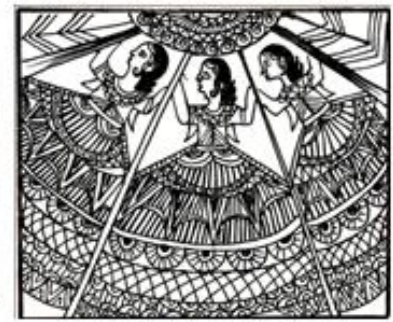

T10

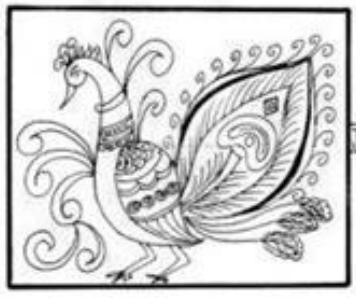

T3

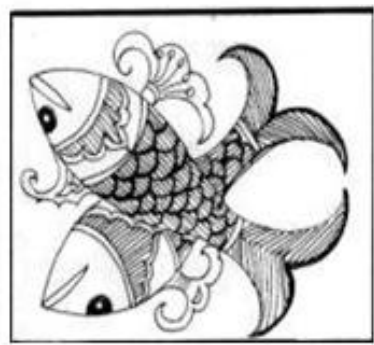

T7

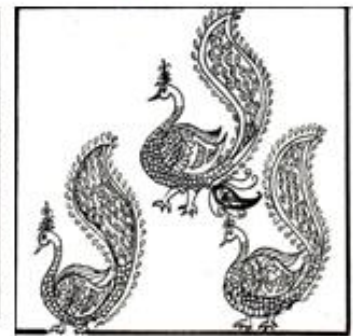

T11

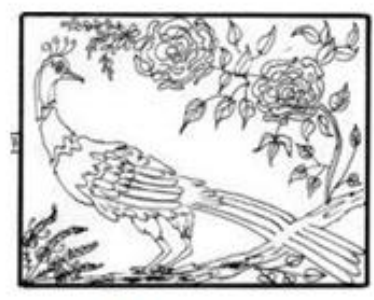

T4

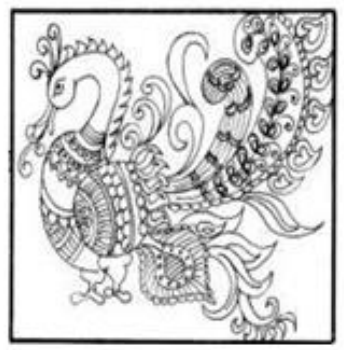

T8

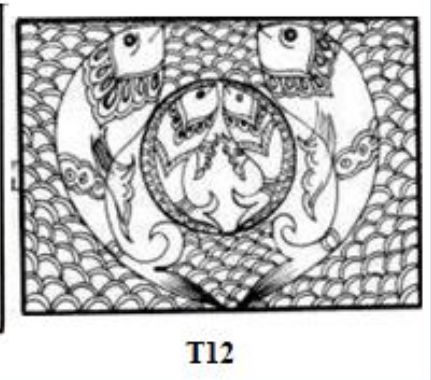

T12

Figure 3: DESIGN FOR TABLE CLOTH

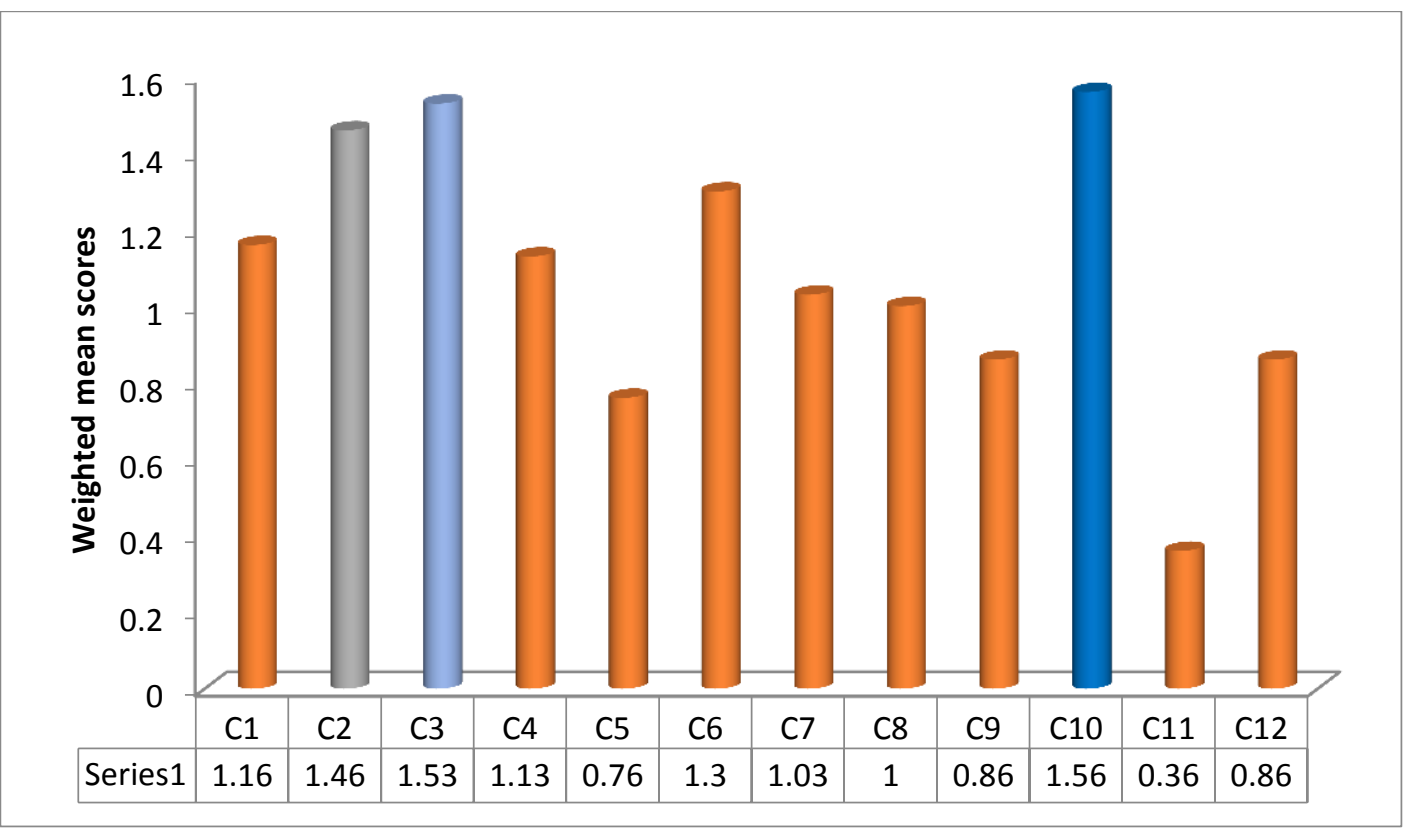

Figure 4: Evaluation of designs for cushion cover 


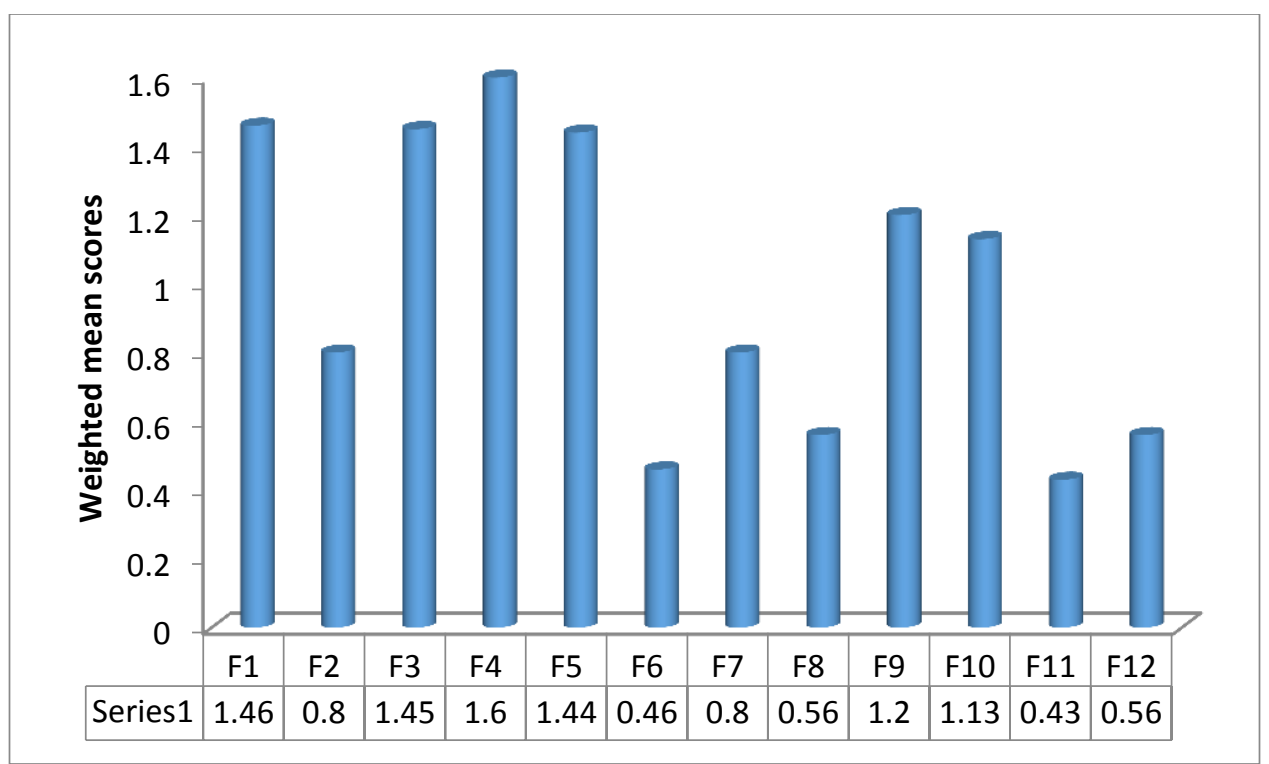

Figure 5: Evaluation of designs for folder

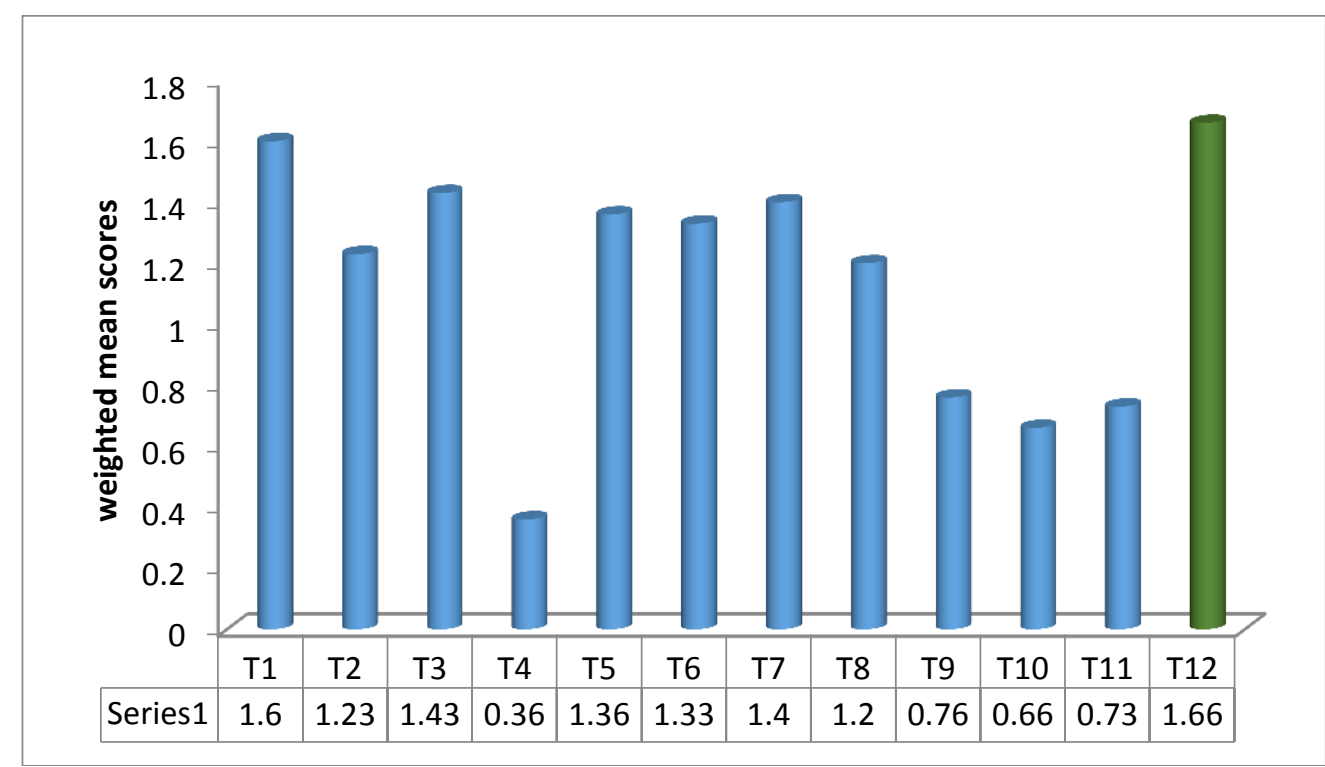

Figure 6: Evaluation of designs for table cloth

\section{PREPARATION OF ARTICLES}

\section{Cushion cover}

Cushion cover of size 16" x16" was inspired from Madhubani painting. A peacock motif with floral design was adapted in centre of cushion cover and geometrical patterns were also adapted for creating border of cushion cover by using hand painting and different types of colours such as red, pink ,blue, green, yellow, orange and black (Fig-7).

\section{Folder}

Folder 13" X10" of size was enthused from Madhubani painting. Stylized peacock motif was adapted for right side of the folder. On the other hand decorative lace as well as golden ribbon 
was also used for decoration purpose. For embellishment different colour's stones were also used (Fig- 8).

\section{Table cloth}

A rectangle shape Table cloth of size 36"X18" was encouraged from Madhubani painting. The fish motif was adapted for center of the table mat. Edges of the table cloth were finished by using crotched lace (silk thread) in saffron colour (Fig-9).

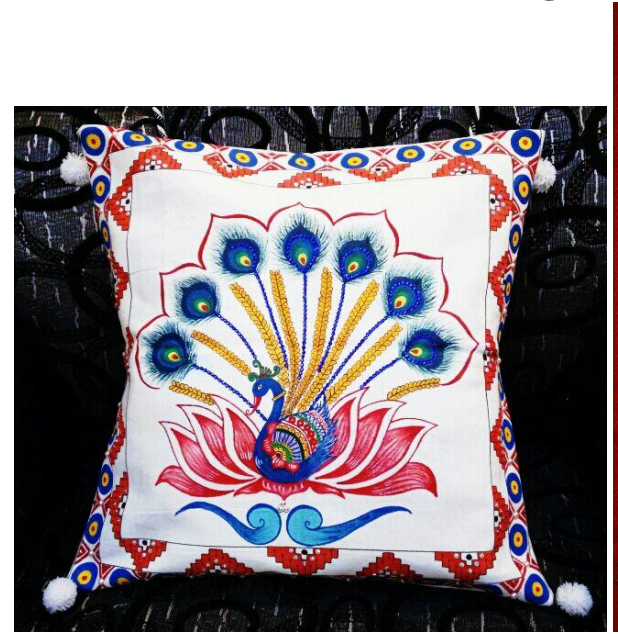

Figure7: Cushion cover

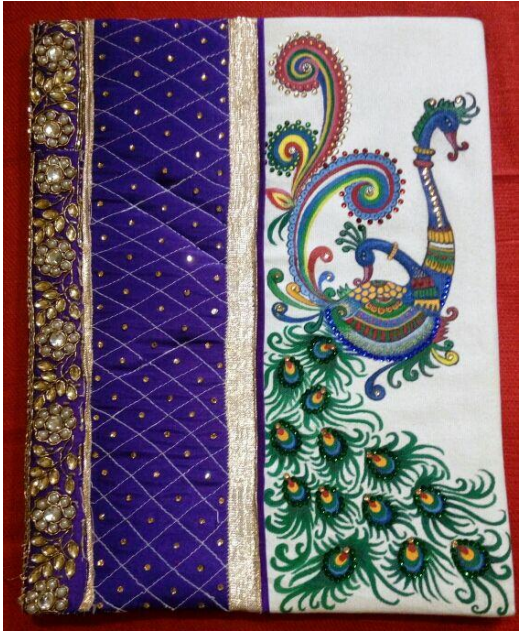

Figure 8: Folder

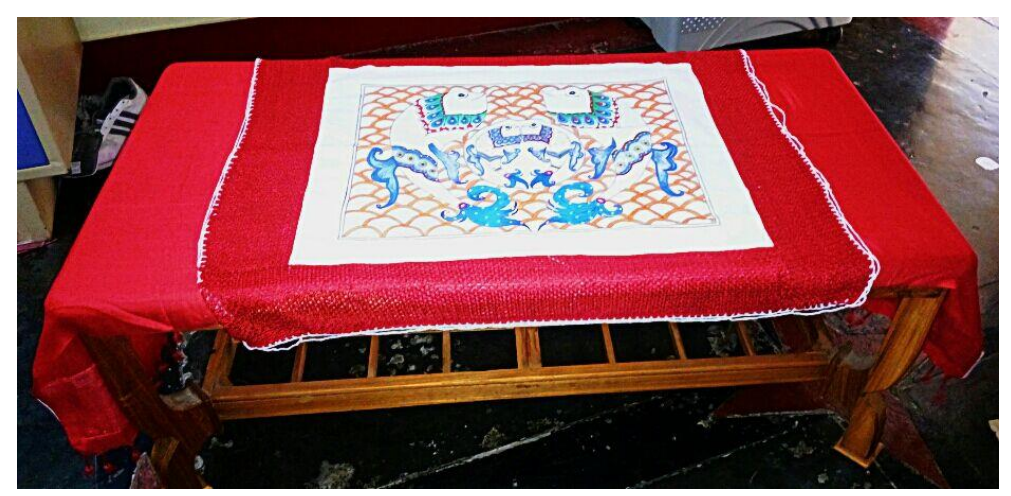

Figure 9: Table cloth

\section{EVALUATION OF DEVELOPED ARTICLE}

It can be seen from Table-1 that table cloth obtained highest weighted mean score 3.46 in case of colour combination. Folder and cushion cover with average weighted mean score 1.83 and 1.56 obtained second and third rank respectively.

Data in Table-2 revealed that table cloth (WMS-3.7) was found the most preferred article by the respondents whereas folder with weighted mean score 1.66 obtained third rank for its innovativeness.

Data in Table 3 showed that majority of the respondents considered table cloth as "best" with respect to their overall appeal with weighted mean score 3.5. Folder was obtained third rank by the respondents (WMS-1.73) for its overall appearance. 
It can be seen from Table 4 that there was variations in the views of consumer over the cost of the articles. 63.3 percent and 76.6 percent of total respondents reported that the cost of cushion cover and table cloth was adequate. The suggested cost for folder was found to be high according to 43.3 percent of the total respondents.

Table 1: Preferences of the respondents for colour combination of the prepared articles

\begin{tabular}{|l|l|l|}
\hline Name of the articles & Weighted mean score & Rank \\
\hline Cushion cover & 1.56 & III \\
\hline Folder & 1.83 & II \\
\hline Table cloth & 3.46 & I \\
\hline
\end{tabular}

Table 2: Preferences of the respondent for innovativeness of the prepared articles

\begin{tabular}{|l|l|l|}
\hline Name of the articles & Weighted mean score & Rank \\
\hline Cushion cover & 2.06 & II \\
\hline Folder & 1.66 & III \\
\hline Table cloth & 3.7 & I \\
\hline
\end{tabular}

Table 3: Preferences of the respondents for overall appeal of the prepared articles

\begin{tabular}{|l|c|l|}
\hline Name of the articles & Weighted mean score & Rank \\
\hline Cushion cover & 2.86 & II \\
\hline Folder & 1.73 & III \\
\hline Table cloth & 3.5 & I \\
\hline
\end{tabular}

Table 4: Opinion of the respondents regarding suitability of quoted price

\begin{tabular}{|l|l|l|l|l|}
\hline \multirow{2}{*}{ Name of the articles } & $\begin{array}{l}\text { Quoted } \\
\text { price }(₹)\end{array}$ & Freq. & Freq. & Freq. \\
\cline { 3 - 6 } & 125 & High & Adequate & Low \\
\hline Cushion cover & 155 & 43.3 & 76.6 & 13.3 \\
\hline Folder & 155 & 3.3 & 16.66 & 40 \\
\hline Table cloth & 195 & 63.3 & 33.3 \\
\hline
\end{tabular}

\section{CONCLUSION}

Madhubani paintings, one of the most celebrated works of art from Bihar are accomplished by generations of skilled artists. Being vibrant and symbolic at the same time, these successfully depict all aspects of tribal life. In other words, these are the arch representative of folk art in visual form. Madhubani paintings is one dominant artistic expression among its peers of handicrafts made by natural resources like Bamboo and other herbal ingredient, arts like siki-mauni, sujni and sitalpati, godhna, sculptures of mythological sama-chakeva and numerous other folk art forms which are very close to daily life style of Maithali rural peoples are equally vibrant.

In fashion world, there is always a demand of something novel and artistic. The blend of Madhubani design with hand painting is providing an imaginative and fresh collection to the 
people who want to adopt their tradition with minute modernization. Adapting and improving the designs refers to modify it such that it will be easier to produce or easier to maintain. With the changing world of fashion the field of textile demands for unique, different and fresh designs which give us the opportunity to use the adapted traditional motifs.

All the designs and the product prepared by us are preferred by the immediate consumers. Thus, in the textile sector the adapted design can be used through the surface enrichment for product diversification and value addition. The continuing market in this art throughart the world is a tribute to the resourcefulness of the women of Mithila who have successfully transferred their techniques of bhitti chitra or wall painting to the medium of paper, and have resisted the temptation to adopt their traditional designs too freely in pursuit of unpredictable public tastes.

This type of work also motivates people to come up with an ingenious work, which indirectly help in upgrading the art and craft.

\section{REFERENCES}

[1] Thakur U (1982) Madhubani painting. Abhinav publication, New Delhi.

[2] Das $N$ (2013) Madhubani paintings: Its existence and possibility, International $J$ of Scientific and Research Publication, Vol 3:2,.

[3] Joshi D N (1985) The meaning of colour and part played by colour in textile designing. Tex Trends 28: 46-47.

[4] Saxena N (2012) Adaptation of cubism era designs for designing home furnishing items. J Man Made Tex In Ind 7:241-43.

[5] Arya D (2014) Ergonomic evaluation of operation performed by art workers involved in Mithila painting in Madhiubani districts: An action research. M.Sc. thesis, GBPAUT, Pantnagar, India.

[6] Sharan M (2012) Madhubani rural art reflecting traditionalism in modernity. http://www.fibre2fashion.com. 